\title{
Review Article The Plurality and Playfulness of Provincial Writing: A Review of Modernity and Provincial Writing: The Case of Manoj Das
}

\author{
Panchanan Dalai, Modernity and Provincial Writing: The Case of Manoj Das. Kolkata: \\ Avenel Press. 2016. ISBN 978-93-80761-92-3. Pages 147. Paperback, Rs 300. \\ Reviewed by Nibedita Bandyopadhyay \\ A Doctoral Candidate of English at the Department of Humanities and Social Sciences \\ Indian Institute of Technology, Kanpur. Email Id: nibeyay@iitk.ac.in
}

The choice of language in literary and cultural spheres has always been subjected to politics, undergirded by the ideologies of power and control. The controversy regarding the choice of the national language in India has caused much unrest in the past, and it is still a matter of discontent to many. Language politics can be traced back to the colonial period. And still, it prevails in the postcolonial India, where English as a language still enjoys an elitist fervor. Writers and critics have compartmentalized themselves over the selection of medium of expression. Some prefer English over the vernaculars, and some the reverse. Salman Rushdie's provocative, yet controversial statement in the introduction to Mirrorwork that contains the Indian English Writings from 1947 to 1997, published in the year 1997 can be cited as an example of the parochialism of certain English educated elites who are yet to overcome their colonial hangover. Rushdie observes, "the prose writing-- both fiction and non-fiction-- created in the period [the fifty years after independence] by the Indian writers working in English . . . is providing to be a stronger and more important body of work than most of what has been produced in the eighteen recognized languages in India, the so-called vernacular languages, during the same time" (1997, p. vii-xx). This single sentence is powerful enough to ignite the age-old controversy involving English and the other vernaculars in India as the appropriate language for the artistic production.

Rushdie's unsubstantial remark, however, betrays a veritable gap between the Indian English writers, and the regional writers writing in the vernaculars. Dr. P. Dalai's insightful book Modernity and Provincial Writing: The Case of Manoj Das is a significant addition to the literary scholasticism of regional writing. Here he has subverted the binaries of different languages and has dismissed the charges of traditionalism, parochialism, and a lack of theoretical consciousness labeled against the vernaculars by foregrounding the works of Odisha's leading bilingual writer Manoj Das. The book incorporates in itself the regional writers of the West like Thomas Hardy, George Eliot, Joyce, J. M. Synge, W. B. Yeats, Henri Bosco, Vasco Pratolini, and others to establish and elaborate Dalai's discourse on the relevance and distinctiveness of regional writing. Regional writings and regional languages are in no way, as Dalai observes, "traditional, uncritical, and parochial" (2016, p. 7). The book appears to be a fitting rejoinder to the myopic critics and their established linguistic hierarchies that fail to grasp the fine nuances of "the pluralities and peculiarities amongst vernacular literatures" as pointed out by Dalai (2016, p. 66) that ironically leads to what G. N. Devy terms as "cultural demoralization", as quoted by Dalai in his book (2016, p. 21). Manoj Das's uniqueness lies in his linguistic dexterity of writing both in English and (c) AesthetixMS 2016. This Open Access article is published under a Creative Commons Attribution Non-Commercial 4.0 International License (http://creativecommons.org/licenses/by-nc/4.o/), which permits non-commercial re-use, distribution, and reproduction in any medium, provided the original work is properly cited. For citation use the DOI. For commercial re-use, please contact editor@rupkatha.com. 
regional language which testifies that fact that if a writer is gifted with enough literary sensibility, the selection of language may not be a threat to him.

After establishing the sovereignty of the vernaculars, the book proceeds to bring to the fore the issues of national identity, geo-cultural specificity, historicity, and above all the enigmatic issue of modernity in the regional writings of India. He favours the use of vernaculars as these can fittingly capture the regional peculiarities in India, not in isolation from other vernaculars but in sync with the influences of each other. Therefore, he contextualizes Manoj Das's work in the framework of Odia as well as Bengali, Punjabi, Hindi, and other literary canons in order to explore the relationship between "modernism, bilingualism, and creativity" as observed by Professor Sachidananda Mohanty in his 'foreword' to this book. Modernism, as commonly believed, is a product of European Enlightenment. But it would be misleading to perceive modernity in Indian literatures as solely a product of Europe. If the concept of modernism underlies fine literary sense and sensibility in theme and realism in technique, then as Dalai observes, Sarala Das's Odia Vilanka Ramayana, Chandi Purana, Kashiram Das's Bangla Mahabharata, and Tulsi Das's Hindi Mahabharata are apt examples of modern literatures conceived much before the beginning of the formal English education in India. Manoj Das and his contemporary Odia writers were influenced both by English education and the legacy of pre- independence Indian literature. Therefore, their writings are chiseled by the wonderful amalgamation of modernist sensibility and regional peculiarities. Eurocentric theories like Marxism, feminism, and psychoanalysis strengthen their critical faculty and Indian folk, myths and legends mould their finer observation of Indian life. Dalai's book by comparing and contrasting different writers from Odisha and other regions confers justice to this stage of transition when young educated minds were caught in the juncture of modernity and traditionalism in the pre and post-independent India. The book is enriched by the exemplary writings of Bankimchandra Chattopadhyay, Michael Madhusudan Dutt of the preGandhian era and Mulk Raj Anand, R. K. Narayan, Raja Rao of post-Gandhian India to show how Manoj Das and his contemporaries were influenced by these writers. Dalai is especially attentive to Bengali literature because Orissa and Bengal being two neighbor states share many sociocultural similarities, and most importantly Manoj Das himself hails from the border district of Balasore sharing its border with West Bengal.

The book is arranged in six chapters. First three chapters of the book, namely, "Modernity and Bilingualism", "Manoj Das and Regional Writing", "Ethnography and Regional Writing: The Case of Manoj Das" map out the issues of modernity, bilingualism, provincial writing and the. The following chapters, "Writing Provinces and Tracking Changing Times", Province, "Patriarchy and Women", "Of Motherhood and Motherhood" speculate how Manoj Das traces out the contemporary 'life and times' and Odia literature, gradual transformation of Odisha from an agrarian state to an industrial one and the role, and status of women and mothers in the changing social scenario. Manoj Das is especially attentive to the plights of the subalterns and their positions in the trajectory of historical, social and cultural transformations. According to Dalai, Manoj Das's writing explores the "political emergency, apathy, duplicity towards peasantry" (2016, p. 67).

The book also captures Das's depiction of the transition of rural Odisha from feudalism to capitalism and the subsequent decay of the Zamindar aristocracies. Das does this almost in the manner of renowned Bengali novels like Tarasankar Bandyopadhyay's "Jalsaghar" (1938), which later on turned into a film by Satyajit Ray and Bimal Mitra's Saheb Bibi Golam (1962) that too got the filmy adaptation in both Hindi and Bengali languages. The change in the socio-economic status after the independence produced a shock to the aristocratic families. They failed to come to 
the terms with the new industrial-capitalistic order of the society. Their nostalgia about the lost grandeur and the deterioration that followed after, are described in such a manner that creates poetry steeped in sadness. However, the suffering of the common people remained the same even after such a huge transformation of the society. Dalai ponders upon issues like Feudalism and sexuality, patriarchal control of the female body, and the subjugation of the females of the marginalized section to the lust of upper-class males, domestic violence, and disproportionate distribution of wages among the male and female labourers. Such novellas like Cyclones and $A$ Tiger in the Twilight depict the historiography of the Zamindar families. While dealing with the social transformation, the book also depicts twilight of freedom struggles against the British. The book rightly points out the ironic treatment of the new rising self-motivated politicians for whom "patriotism is nothing more than finding a favourable seat in the state legislature" (2016, p. 47).

Many of Das's stories, as Dalai has discussed, show the resistance of the villagers to the state hegemony like development at the cost of local environment. In this respect, the novella Cyclones (1987) by Manoj Das can be read as the paradigm of ecocriticism. The novella depicts the environmental degradation of an eco-friendly village, where both the local government officials and greedy corporate join hands to devastate the environment for money. Das's writing touches burning issues of environment like the construction of dams by dislocating poor people, unmindful felling of trees, and maltreatment of people who are closer to nature that leads social activists and writers like Medha Patkar and Arundhati Roy to raise their voices. Dalai's book is enhanced by his dialogue with different literary theories and his humanitarian grounding of the act of criticism.

Manoj Das is truly sympathetic towards the struggles that the females undergo in the patriarchal social setup of India. He has presented the true image of Indian mothers' hardships to sustain their families. The image of motherhood, for example, often becomes oppressive for the poor mothers. "Lakshmi's Adventure", a short story by Das, depicts the heart-rending pangs of a poor mother who cannot afford to buy a frock for her girls. Expanded in the bigger canvas, the father's debt to the money-lender in the same story depicts very common scenarios of rural India where till today poor farmers are committing suicides for failing to repay the debts. Thus, parenthood for the poor people often becomes an ordeal in the capitalist order of the day.

Das's writing as explored by Dalai can be fitted into the trajectory of feminism. "The Poison Girl", a short story, deals with the compulsion of a woman to take prostitution to earn her livelihood and the society's subsequent rejection of her. His other female characters like Lalita, Heera, Gauri, Sati though victims of male oppressions, are unique in their individuality, beauty, profession, and their struggle for livelihood.

The book is, therefore, a worthy and timely contribution to the meager researches done on Manoj Das, and especially in English. Apart from being one of the few critical books on Das, the book also opens up other unexplored dimensions of Das: the hermeneutics of Das's creative career and socio-cultural transformation of Orissa; the semblance of Bengali influence, the presence of homosociality, the treatment of female issues, Odia subaltern class, etc. to name a few. In the final analysis, Dalai's literary oeuvre emerges to be perceptive, yet free from redundancy, superfluous linguistic and theoretical jargons that make the book easily accessible to every type reader. 


\section{References}

Dalai, P. (2016). Modernity and Provincial Writing: The Case of Manoj Das. Kolkata: Avenel Press.

Rushdie, Salman (1997). “Introduction.” In Salman Rushdie and Elizabeth West (Eds.), Mirrorwork (vii-xii). New York: Henry Holt.

Nibedita Bandyopadhyay is a doctoral candidate of English at the department of Humanities and Social Sciences, Indian Institute of Technology Kanpur, India. She is a recipient of Junior Research Fellowship (JRF), conferred by University Grant Commission. Recently, she presented her research work in American Studies Association, Denver, U. S. 